\title{
Religião e patriotismo: o anticomunismo católico nos Estados Unidos e no Brasil nos anos da Guerra Fria
}

Carla Simone Rodeghero ${ }^{1}$

Universidade Federal do Rio Grande do Sul.

RESUMO

$\mathrm{O}$ artigo analisa e compara o anticomunismo católico no Brasil e nos Estados Unidos no período da Guerra Fria. Depois de situar o campo de estudos constituído no Brasil sobre o tema, discute as relações entre americanismo e anticomunismo, procurando situar o catolicismo norte-americano neste meio. Utiliza-se de uma produção recente sobre cultura da Guerra Fria nos Estados Unidos. Levanta, finalmente, uma série de elementos de comparação sobre a forma que o anticomunismo católico assumiu nos dois países.

Palavras-chave: Anticomunismo católico; Guerra Fria; Brasil/Estados Unidos.

\section{ABSTRACT}

This article analyses and compares the Catholic anticommunism in the Brazil and in United States during the Cold War years. After showing the recent studies produced in Brazil about the fight against communism, it discusses the relationship between Americanism, anticommunism and Catholicism. This step is based on recent historical research about the Cold War culture in the United States. Finally, it makes comparisons between the forms that anticommunism assumed in each country.

Keywords: Catholic anticommunism; Cold War; Brazil/United States.

O presente artigo analisa e compara o anticomunismo católico nos Estados Unidos e no Brasil no período da Guerra Fria. Faz parte de um estudo mais amplo a respeito das diferentes configurações e recepções que o combate ao comunismo teve, no Brasil, entre 1945 e $1964^{2}$. Após elencar as principais questões levantadas por estudos sobre anticomunismo produzidos recentemente no Brasil, a análise se dirige para a relação entre americanismo e anticomunismo, situando o catolicismo norte-americano neste quadro. $\mathrm{O}$ passo seguinte é realizar comparações entre o anticomunismo católico no Brasil e nos Estados Unidos, momento em que também serão apresentados elementos sobre a face brasileira deste fenômeno. É importante destacar, todavia, que foi feita a opção de tratar mais demoradamente o caso norte americano, tendo em vista o fato de que os estudos sobre os Estados Unidos são pouco freqüentes na historiografia brasileira. 
A HISTORIOGRAFIA SOBRE ANTICOMUNISMO NO BRASIL

O fenômeno do anticomunismo diz respeito a uma postura de oposição sistemática ao comunismo ou àquilo que é a ele identificado, uma oposição que se adapta a diferentes realidades e se manifesta por meio de representações e práticas diversas. $\mathrm{O}$ anticomunismo é o conjunto das atividades realizadas por grupos diversos, que constróem e se guiam por um conjunto de representações que tem sido chamado de imaginário anticomunista. Trata-se de atividades como produção de propaganda, controle e ação policial, estratégias educacionais, pregações religiosas, organização de grupos de ativistas e de manifestações públicas, atuação no Legislativo, etc.

Nos últimos 15 anos foram produzidos vários estudos sobre anticomunismo nos programas brasileiros de pós-graduação em História ou áreas afins ${ }^{3}$. Entre as perguntas que os historiadores e outros estudiosos têm dirigido aos registros que sobreviveram desse conjunto de práticas estão aquelas relacionadas ao conteúdo do discurso anticomunista, através das quais se procura compreender como os comunistas eram representados: que tipo de perigo eles trariam à sociedade brasileira, quais seriam seus planos, quais suas relações com o "comunismo internacional" configurado especialmente pela União Soviética, quais as suas estratégias de ação, qual o grau de sua "infiltração" em setores estratégicos da sociedade brasileira, qual o peso do partido comunista nas disputas políticas, no sindicalismo, no movimento estudantil, etc. A resposta a estas perguntas permite entender os principais componentes do discurso anticomunista e captar o diagnóstico que os anticomunistas faziam de uma realidade que lhes parecia impregnada de ameaças.

Na explicitação desse diagnóstico, tem sido possível encontrar elementos para responder a dois outros conjuntos de questões: o primeiro diz respeito às imagens utilizadas para caracterizar o comunismo e os comunistas e os meios pelos quais as mesmas são veiculadas. $\mathrm{O}$ segundo são questões que os historiadores podem dirigir aos anticomunistas enquanto grupos que constroem sua própria identidade em oposição àqueles que seu discurso e sua prática denunciam.

No que se refere ao primeiro conjunto, pode-se salientar a escolha de determinadas imagens que se repetem no tempo e que relacionam o comunismo ao inferno e os comunistas ao demônio, que representam esses como vermes, abutres, polvos, serpentes, que os relacionam à doença, ao estrangeiro, à traição, à ilusão. Esse campo tem sido bastante explorado pela historiografia permitindo a explicitação do imaginário anticomunista. No caso brasileiro, pode-se destacar a presença dessas imagens associadas a um evento particular: o movimento de 1935, que ficou conhecido como Intentona Comunista, e a liderança de Luiz Carlos Prestes. Outro exemplo é o que se pode encon- 
trar no seio da Igreja Católica, relacionando o comunismo com perseguições à Igreja no México, na Espanha e na Rússia.

O segundo conjunto é composto por questões relacionadas a quem eram esses indivíduos e grupos que deixaram registros de sua inserção na luta contra o comunismo. Daí que pesquisas têm sido dirigidas a grupos com práticas anticomunistas específicas, como certos partidos políticos, a Igreja Católica, o Exército, a polícia, órgãos de imprensa, órgãos do governo federal, estadual, organizações criadas exclusivamente para o combate ao comunismo, entidades empresariais ou sindicais, etc. A análise do discurso e das práticas anticomunistas destes grupos permite não só compreender a forma como eles encaravam o perigo comunista, mas também a forma como eles utilizavam esta "batalha" para construir sua própria identidade, garantir a coesão interna e o reconhecimento externo. Assim, é possível observar como instituições como a Igreja Católica e o Exército garantem seus espaços nas disputas político-ideológicas de uma época, ou como certos governos buscam legitimidade utilizando o "perigo vermelho" como uma ameaça que lhes cabe enfrentar em nome da sociedade como um todo.

Um outro conjunto de questões que se pode vislumbrar nos estudos sobre o tema é o do cruzamento do discurso anticomunista com a organização e ação dos comunistas. Isso está relacionado com a possibilidade de descobrir em meio a registros sobre o anticomunismo, indícios relacionados à organização e às atividades dos próprios comunistas ou daqueles que eram a eles identificados. Ou ainda, de questionar se o diagnóstico que os anticomunistas faziam correspondia com o nível de organização dos comunistas em determinadas realidades, e se o perigo que eles pressentiam tinha chances de se concretizar.

Um outro campo de questões que está apenas começando a ser explorado é o que diz respeito à recepção, ou seja, como o fenômeno do anticomunismo poderia ser entendido a partir daqueles indivíduos e grupos que foram alvo das ou que foram atingidos pelas campanhas anticomunistas. Nesta direção, estaria o reconhecimento das defasagens e transformações ocorridas ao longo do processo de produção, circulação e recepção do anticomunismo e também das possibilidades de apreensões e "leituras" diversas sobre o mesmo fenômeno, por grupos diferentes.

Assim, guiados por uma ou outra das questões acima esboçadas, os estudos sobre o anticomunismo brasileiro têm explorado a constituição do imaginário anticomunista, revelando a persistência de certos temas e imagens em épocas diferentes; analisando grupos e instituições que no Brasil se dedicavam às campanhas anticomunistas (como foi o caso da Igreja Católica, dos integralistas, do Exército, da Cruzada Brasileira Anticomunista, de diversos órgãos imprensa, do aparato policial, etc.); mostrando que o anticomunismo 
assumiu diferentes papéis e formas em conjunturas específicas, como naquelas em que ele parece ter sido mais intenso, de 1935 a 1937 e de 1961 a 1964. O conjunto de análises pontuais mostra, enfim, que o anticomunismo esteve presente nas disputas políticas brasileiras de grande parte do século XX.

Uma das instituições que mais se dedicaram ao combate ao comunismo no Brasil foi a Igreja Católica. O anticomunismo católico no Brasil se organizava a partir da infra-estrutura já existente na Igreja e se beneficiava das boas relações que a hierarquia mantinha com governos e grupos dominantes. Era veiculado através de pronunciamentos de autoridades católicas em jornais, alocuções radiofônicas, solenidades de inauguração, missas especiais. Recheava as páginas de jornais católicos e permeava o conteúdo de programas de rádio; era difundido nas escolas, nos grupos da Ação Católica, nos seminários onde se formavam os novos padres. Circulava na forma de livros, revistas, cartazes, panfletos e santinhos, impressos nas gráficas e editoras católicas. Foi, muitas vezes, canalizado através do trabalho de entidades como a Liga Eleitoral Católica (LEC), os Círculos Operários (COs) e as Frentes Agrárias. Transformou-se em tema para os sermões dominicais nas pequenas e grandes paróquias espalhadas pelo País, pregação que permanece na memória de muitos católicos até hoje. Incentivou multidões a irem às ruas para rezar o terço, pedindo proteção a Deus contra a ameaça do comunismo.

A possibilidade de relacionar e comparar o anticomunismo católico no Brasil e nos Estados Unidos surgiu a partir da conjugação de dois elementos: a experiência prévia de pesquisa sobre o combate católico ao comunismo no Rio Grande do $\mathrm{Sul}^{4}$, e uma pesquisa posterior que utilizou fontes diplomáticas norte-americanas para explicitar como os funcionários que trabalhavam nos Consulados e na Embaixada — ou ainda em outras agências dos Estados Unidos - situados no Brasil, avaliavam as campanhas anticomunistas que estavam em curso no País entre 1945 e 19645. Essas fontes permitiram levantar um olhar norte-americano sobre o anticomunismo brasileiro, suscitaram questões sobre o próprio anticomunismo norte-americano, e conduziram à leitura de estudos realizados naquele país a respeito das relações entre americanismo e anticomunismo. Nesse processo foi possível perceber no anticomunismo católico uma série de nuances relacionadas, entre outras coisas, ao lugar ocupado pelo catolicismo em cada uma dessas sociedades.

\section{AMERICANISMO E ANTICOMUNISMO}

Antes de adentrar no anticomunismo católico norte-americano, serão feitas algumas considerações a respeito da relação entre americanismo e anticomunismo. Entendo o americanismo como uma espécie de "ideologia na- 
cional" com traços de longa data, que foram reforçados no período posterior à Segunda Guerra Mundial, especialmente na década de 1950. Estes traços são o individualismo, a crença na iniciativa privada, a defesa das liberdades políticas, um patriotismo acrítico, a valorização da religião, e a confiança nas autoridades e nas instituições. De acordo com Stephen Whitfield - que em The Culture of Cold War estudou a cultura da Guerra Fria na sociedade norte-americana, especialmente em veículos de comunicação de massa -, a defesa do americanismo era o outro lado da estigmatização do comunismo. O americanismo é descrito por este autor como sendo um sistema de crenças:

O sistema de crenças que a maioria dos norte-americanos de classe média considerava sua herança - o tradicional compromisso com o individualismo competitivo na vida social, com o acento liberal nos direitos na vida política e com a iniciativa privada na vida econômica — foi adaptado às crises da Guerra Fria. Um patriotismo acrítico, muitas vezes, deu a forma às interpretações do passado ${ }^{6}$.

Tudo isso esteve somado, de acordo com o mesmo autor, à confiança nas instituições e na autoridade, e a uma visão positiva dos bons resultados nos negócios, compondo assim o American way of life. E, como o inimigo era acusado de ser materialista, o respeito pela religião também se manteve como peça importante do americanismo.

Essa visão sobre os Estados Unidos era aceita como se estivesse livre de ideologia por um grande número de norte-americanos que, assim, habitava um universo mental reconhecível. Apesar de ser possível perceber gradações na aceitação e defesa deste sistema de crenças, ele tinha poderosos canais de divulgação que tendiam para a criação de um consenso. Veja-se o exemplo do conteúdo veiculado pelos livros escolares. Whitfield utiliza-se de um estudo de Frances Fitzgerald para mostrar a visão sobre os Estados Unidos presente neles.

A América era perfeita: a maior nação do mundo e a incorporação da democracia, da liberdade e do progresso tecnológico. Para eles, o país nunca mudara de maneira importante: seus valores e suas instituições e práticas permaneciam constantes desde o tempo da Revolução norte-americana ${ }^{7}$.

Nos livros escolares, também segundo Fitzgerald, a palavra "democracia" se tornou sinônimo de statu quo e oposição ao fascismo e ao comunismo. A palavra "capitalismo" raramente aparecia. Parecia haver mais entusiasmo ao falar da livre iniciativa do que da garantia das liberdades. Os textos didáticos também passavam a impressão de que, nas relações exteriores, os Estados Unidos agiam por filantropia e com uma boa vontade desinteressada. Esse tipo de visão a respeito de si e do seu país foi desafiado - e refor- 
çado - nos anos da Guerra Fria, quando os norte-americanos tiveram que se confrontar com um inimigo, o comunismo. Na apresentação da obra $R e-$ thinking Cold War Culture, os historiadores Peter Kuznick e James Gilbert apontam como marcas particulares da Guerra Fria a ameaça nuclear, o antisovietismo, as guerras secretas, e o complexo militar industrial. Procurando destacar o que seriam características da Guerra Fria e o que seriam tendências de abrangência maior, os autores defendem que o principal efeito dessa guerra foi psicológico, pois:

(...) persuadiu milhões de norte-americanos a interpretar seu mundo em termos de insidiosos inimigos em casa e no exterior que os ameaçavam com a aniquilação nuclear e de outras formas. Ver o mundo através destas lentes escuras e distorcidas e estabelecer políticas globais e domésticas para conter estas ameaças ao mesmo tempo imaginárias e reais, foi e é, então, o maior impacto da Guerra Fria.

Os autores também destacam a polarização ideológica que se produziu entre capitalismo e socialismo, com suas conseqüências internas e externas: o inimigo - comunismo soviético - era considerado tão diabólico que em nome de sua destruição poderia até se arriscar a destruição da própria civilização com o uso das armas atômicas. Além disso, a União Soviética não era apenas inimiga nos campos militares, da economia e da geopolítica. Ela era uma inimiga ideológica comprometida, em teoria, com a igualdade social e econômica e com a socialização dos meios de produção, o que colocava um desafio a uma nação como os Estados Unidos, comprometida com o capitalismo.

Os efeitos dessa polarização se fizeram sentir tanto na política externa quanto na doméstica. Falando sobre esta última, os mesmos autores comentam que o debate político foi distorcido em muitas oportunidades, na medida em que os conservadores criticavam soluções para os problemas sociais que tivessem tons social-democratas ou de esquerda. Nesse quadro, a esquerda norte-americana foi efetivamente marginalizada e o campo possível de debates foi estreitado.

Os efeitos da Guerra Fria e o preço pago pela sociedade norte-americana pela histeria anticomunista que a caracterizou são avaliados de forma ainda mais negativa por Whitfield ${ }^{9}$. Este autor, que também faz fortes críticas ao comunismo, afirma que os Estados Unidos se igualaram ao sistema que pretendiam criticar na medida em que cercearam as liberdades dos seus cidadãos, arruinaram inúmeras carreiras, impediram o público de fazer suas próprias escolhas no mercado de idéias, etc. Para ele, uma sociedade que por razões políticas impõe padrões para a sua arte ou solicita aos seus artistas certos tipos de testes de cidadania, como lealdade acrítica e arrependimento, é muito parecida com uma sociedade totalitária. 
A defesa do americanismo e o combate ao comunismo foram levados a efeito, nos anos da Guerra Fria, com o auxílio de um grande aparato jurídico e administrativo. Tal combate era regulamentado por uma série de tribunais e de leis, o que poderia lhe dar mais sistematicidade e eficiência ${ }^{10}$. O exemplo mais expressivo é o House Committee on Un-American Activities (HUAC), que funcionou de 1938 a 1975. Em 1945 se tornou o primeiro comitê permanente encarregado de investigar propaganda e atividades consideradas subversivas e "não-americanas". De 1945 a 1957 realizou pelo menos 230 audiências nas quais mais de três mil pessoas testemunharam. Seus alvos variaram ao longo do período. Em 1948, por exemplo, investigou a alegada infiltração comunista em agências do governo federal, recolhendo informações que possibilitaram a condenação do ex-oficial do Departamento de Estado, Alger Hiss. Em 1951, investigou a infiltração comunista na indústria cinematográfica. No ano seguinte, prestou mais atenção aos sindicatos e também lançou um ataque a duas instituições norte-americanas - Harvard University e Massachusetts Institute of Technology - por elas não terem suspendido professores do seu quadro docente que foram considerados comunistas. Em 1953, o comitê convocou para depoimentos o ex-presidente Truman e o ex-secretário de Estado James Byrnes, que se recusaram a comparecer.

Além da "eficiência" que este tipo de instrumento poderia dar ao combate doméstico ao comunismo, o período da Guerra Fria foi marcado, nos Estados Unidos, pela disseminação do anticomunismo através de veículos os mais diversos. A publicação de livros, que se tornavam best-sellers ou que tinham seus capítulos publicados em centenas de jornais por todo o país, a transformação dos mesmos em filmes pelos estúdios de Hollywood ou em programas de televisão foram elementos extremamente eficientes para a divulgação do medo do comunismo e para a conformação de um clima de vigilância, por um lado, e para a aceitação desse quadro como algo natural, por outro.

Um exemplo de exploração do anticomunismo no ramo editorial foi o livro The FBI Story de Don Whitehead, lançado em 1956 e serializado em 170 jornais, que teve sua introdução assinada pelo diretor do FBI, J. E. Hoover. Ficou por 38 semanas na lista dos best-sellers e foi depois transformado em filme pela Warner Bros. Um livro do próprio Hoover, Masters of Deceit - publicado no Brasil com o título Mestres do Embuste - foi best-seller em 1958, quando vendeu dois milhões e quinhentas mil cópias. Nos doze anos seguintes, teve 29 reedições ${ }^{11}$.

O anticomunismo nos Estados Unidos não foi, porém, uma novidade da Guerra Fria ${ }^{12}$. Uma primeira grande onda de medo do comunismo atingiu o país no final da década de 1910 . Nesta fase, seu alvo estava localizado nas classes baixas, entre trabalhadores nascidos no estrangeiro e que estariam trazendo doutrinas "alienígenas" do Velho Mundo. Somou-se a isso o impacto da 
Revolução Russa. De acordo com Joel Kovel, em Red Hunting in the Promised Land, a presença de milhões de imigrantes no país mobilizava fantasias e medos sobre os estrangeiros. E este medo foi transportado para o campo político, já que aos estrangeiros faltava o selo de "americanismo" e que uma minoria deles era portadora de doutrinas radicais. O mesmo autor comenta que, na época, os imigrantes não eram os únicos estrangeiros. Também eram vistos desta forma os afro-americanos cujas expectativas de integração estavam crescendo e gerando levantes.

Durante o período entreguerras, a "ameaça vermelha” foi redefinida: não se tratava mais do perigo da insurreição, mas de uma conspiração dirigida por Moscou e que usava as estratégias da infiltração, manipulação e sedução ideológicas. Nesse período, o alvo interno eram as políticas do New Deal ${ }^{13}$. criticadas especialmente pelos republicanos pela excessiva regulamentação governamental e pelo apelo que o programa de governo representava para os eleitores.

Mesmo durante a Segunda Guerra, quando a União Soviética era aliada dos Estados Unidos, muitos norte-americanos - católicos patriotas, protestantes fundamentalistas, socialistas democráticos, e muitos sindicalistas permaneceram firmes em sua hostilidade tanto ao comunismo doméstico quanto ao internacional. Posteriormente, a Guerra Fria aproximou mais o governo federal deste tipo de demanda do eleitorado. Com o aprofundamento da Guerra Fria e com a administração de Truman legitimando a campanha doméstica contra a esquerda, muitos estados norte-americanos passaram a aprovar leis de lealdade, bem como leis de controle dos comunistas.

O jogo político partidário interno dos Estados Unidos também foi intensamente marcado pelo anticomunismo ${ }^{14}$. A acusação de tolerância em relação ao comunismo foi usada, por exemplo, pelos republicanos para atingir os democratas, na eleição em que Eisenhower substituiu Truman. As estratégias reformistas do New Deal e depois do New Fair Deal foram acusadas de fazerem parte de um continuum que levaria a Moscou. Os democratas eram freqüentemente rotulados como pinks. Os republicanos criticavam a "política de contenção" adotada por Truman que definia o sentido da ação dos Estados Unidos como o de conter os avanços do campo comunista.

Mesmo levando em conta estes antecedentes, é possível dizer que os anos 1950 foram a década em que a preocupação com a ameaça comunista interna foi mais intensa nos Estados Unidos. A primeira metade da década viu a ascensão e a queda do senador Joseph McCarthy e, no entremeio, exemplos da histeria anticomunista que ele desencadeou, canalizou e representou. Algumas poucas palavras serão ditas a respeito do fenômeno que ficou conhecido como macartismo.

O senador republicano de Winsconsin tornou-se famoso a partir de 1950 
quando lançou-se numa cruzada anticomunista sem precedentes em sua proporção, no cenário doméstico norte-americano. Muito foi escrito sobre McCarthy e o macartismo ${ }^{15}$. Os estudos têm enfocado a questão a partir dos mais diferentes ângulos: análise da personalidade e do currículo do senador; relação do macartismo com o perigo de infiltração comunista no país, especialmente nos órgãos governamentais; papel do senador e de sua campanha no jogo político-partidário; relação entre estruturas de combate ao comunismo em nível estadual e federal; ataque a alvos específicos, como as universidades ou o mundo artístico de Hollywood; relação com o movimento dos direitos civis e o movimento pacifista; memórias de atingidos pela perseguição no período; relação entre o fenômeno, o anticomunismo e o americanismo, etc. Há entre tais estudos aqueles mais preocupados com os acontecimentos que marcaram a ascensão - e queda - de McCarthy; aqueles que têm preocupações analíticas mais fortes; sem falar nos que são escritos ou para defender a cruzada anticomunista ou para defender os atingidos por ela.

Em meio a esse universo de estudos, o que interessa aqui é dar uma visão sintética do que foi o macartismo, dentro da perspectiva de que o fenômeno foi um dos pontos altos de uma cultura política doméstica que já estava sendo construída, mas que ganhou reforço com o contexto da Guerra Fria e com as disputas partidárias do começo dos anos 50. O macartismo, então, estava sendo encarado como um ponto alto - e, portanto, mais visível que os demais - de uma cultura na qual o anticomunismo tinha solo para crescer e prosperar.

Num discurso proferido em 9 de fevereiro de 1950, o senador McCarthy afirmou ter em mãos uma lista de 205 membros do Partido Comunista trabalhando no Departamento de Estado ${ }^{16}$. O Secretário de Estado, segundo o senador, teria conhecimento desse fato. A lista não foi revelada na ocasião, mas acendeu a curiosidade da imprensa, bem como dos políticos. Uma repercussão importante foi a criação, pelo Senado, de um subcomitê para investigar as acusações do senador. Como McCarthy não possuía provas, sua amizade com o diretor do FBI, J. E. Hoover, foi oportuna e permitiu que o senador tivesse acesso a arquivos secretos do FBI que lhe poderiam ser úteis.

Nas audiências do referido comitê, McCarthy acusou diversas pessoas de ligação com os comunistas, as quais eram posteriormente convocadas e negavam as acusações. Mesmo que geralmente o subcomitê concluísse que não havia fundamento nas acusações feitas, as atividades desse órgão providenciaram grande publicidade para McCarthy que começou a receber apoio de muitos norte-americanos, desiludidos com a política doméstica e internacional de quase duas décadas de governo democrata. O desencadear da Guerra da Coréia, por exemplo, foi visto pela oposição como resultado da falta de 
vontade da administração Truman de assumir uma postura mais dura diante da expansão do comunismo no Extremo Oriente.

Em 1952, os republicanos conquistaram a maioria das cadeiras no Senado e McCarthy recebeu a presidência de dois comitês relacionados à vigilância anticomunista, o Government Operations Committee e o Permanent Subcommittee of Investigations. Logo em seguida, um presidente republicano assumiu seu cargo. Eisenhower, apesar de não concordar com os métodos e a campanha de McCarthy, recusou-se a confrontá-lo diretamente.

A CIA também foi alvo de acusações: ela estaria sendo infiltrada por agentes da espionagem soviética. O mesmo estaria acontecendo com a International Information Agency, um setor do Departamento de Estado responsável pela Voz da América e que também mantinha dezenas de bibliotecas no exterior, as quais foram acusadas de conter livros escritos por comunistas ou por simpatizantes.

Em 1954, McCarthy denunciou a infiltração comunista no Exército norte-americano, pressionando para investigar os arquivos confidenciais da instituição. Queria com isso buscar indícios sobre espionagem realizada por cientistas civis que trabalhavam para o Exército. Suas solicitações não foram atendidas e as controvérsias entre as duas partes acabaram sendo expostas a público e resolvidas durante uma série de audiências (Army-McCarthy Hearings), conduzidas pelo Permanent Subcommittee of Investigations que normalmente, mas não nessa ocasião, era dirigido pelo próprio senador. Nessas audiências, transmitidas pela televisão, o público teve conhecimento das técnicas utilizadas por McCarthy. Os colegas republicanos começaram a se afastar dele e, logo em seguida, o Senado aprovou um comitê para recomendar um voto de censura, o que aconteceu em dezembro de 1954. O senador não se recuperou politicamente.

A força que o macartismo teve na primeira metade da década de 1950 pode ser entendida como o resultado da conjugação de uma série de ingredientes: na conclusão de um estudo sobre o papel que a política estadual teve no desenvolvimento do "medo vermelho", entre 1935 e 1965, M. Heale destaca a importância dos seguintes ingredientes para a eficácia do anticomunismo: a presença de comunistas ou outros radicais atuando numa cidade ou estado; a existência de lobbies patriotas (grupos de cidadãos, organizações empresariais, grupos de sindicalistas, grupos de católicos ou protestantes, grupos brancos defensores da separação racial); a criação de redes que interligassem grupos anticomunistas locais, estaduais e federais; a existência de altas autoridades estaduais recrutadas para esta causa; o exemplo e o apoio federal. $\mathrm{O}$ autor também chama a atenção para o contexto internacional da Guerra Fria, no qual os grupos anticomunistas locais tenderam a se reforçar com a deterioração das relações entre Estados Unidos e União Soviética ${ }^{17}$. 
Além dos elementos citados, é preciso atentar para o lugar da religião no seio do anticomunismo doméstico norte-americano. Durante a Guerra Fria, ainda segundo Whitfield, houve uma grande demanda por salvação e um surto de piedade nos Estados Unidos.

É mais provável que certos traços históricos se reafirmaram, como a tendência a igualar fé com sucesso individual e prosperidade e o pressuposto de que o bemestar nacional era um sinal da aprovação divina. O que intensificou tais crenças foi a necessidade de combater um sistema político que era, acima de tudo, definido como sem Deus ${ }^{18}$.

Assim, a pertença a uma Igreja e uma atitude abertamente favorável em relação à religião se tornaram formas de afirmar o American way of life, especialmente porque a União Soviética e seus aliados assumiram oficialmente o ateísmo. Nesse quadro, ir à igreja regularmente era um escudo contra a suspeita de subversão. Dessa forma, o que aconteceu nos anos 50 não foi um revivecimento da crença religiosa, mas sim da crença na religião, já que os benefícios da devoção não seriam místicos, metafísicos, existenciais, psicológicos ou éticos. Seriam políticos e sociais. A teologia dos anos 50 baseava-se na conviç̧ão de que a religião era símbolo da nacionalidade norte-americana muito mais do que na crença na existência de Deus. $\mathrm{O}$ caso católico é expressivo disso.

\section{CATOLICISMO, AMERICANISMO E ANTICOMUNISMO}

Vários autores que analisam a relação entre catolicismo, americanismo e anticomunismo têm defendido que os católicos norte-americanos tiveram a oportunidade de ser reconhecidos como verdadeiros cidadãos do seu país ao se integrarem na grande luta que mobilizava a todos - independentemente da religião - contra um inimigo comum ${ }^{19}$. Sendo anticomunistas, eles poderiam ser autenticamente católicos e autenticamente norte-americanos. Isso pareceu de grande importância para uma minoria católica dentro de um país predominantemente protestante.

Em estudo sobre o anticomunismo católico dos anos 30, Prelude of the Cold War, Robert Frank conta que a Igreja Católica era vista como um "cavalo de Tróia” dirigido pelo Vaticano, que estava apenas esperando o momento para tomar as rédeas do governo e formar um Estado católico. Era vista como uma Igreja estrangeira, largamente freqüentada por imigrantes, que usava em seus rituais uma língua estrangeira. A acusação de estrangeiridade também é descrita por Donald Crosby em God, Church and Flag, para explicar 
porque os católicos - tanto os que apoiaram quanto os que se opuseram a McCarthy - tinham uma forte preocupação em expressar seu patriotismo.

O rótulo de estrangeiro pairou, por muito tempo, sobre as cabeças dos católicos tendo em vista que, nas palavras desse último autor, a história do catolicismo norte-americano é uma

(...) longa crônica de uma população nascida no estrangeiro que lutou por três séculos para abandonar o seu status imigrante mas nunca pareceu totalmente norte-americana. Por cerca de trezentos anos, seus críticos os acusaram de dever lealdade a um poder estrangeiro (o papa), de falar línguas estranhas, de praticar rituais religiosos exóticos, de manter seu próprio sistema de moral e, pior de tudo isso, de sustentar suas escolas privadas, ao invés do sistema de escolas públicas ${ }^{20}$.

Mas essa visão hostil era alimentada pela "mentalidade de gueto" cultivada pelos próprios católicos. De acordo com Frank, a população católica estava geograficamente separada da protestante. A hierarquia intensificava a separação por meio de organizações sob o controle do clero (como associações de professores, advogados, médicos, etc.), de um sistema educacional e de uma mídia, separados. Para o autor, a postura de defesa, a intolerância e a

474 hostilidade eram as marcas do gueto e de uma retórica que parecia calculada para perder amigos.

Situações particulares dos anos 30 contribuíram para este isolamento. Em 1933, os Estados Unidos, sob Roosevelt, reconheceram a União Soviética. Isso foi visto como um aval ao marxismo. Logo depois, em 1936, os católicos se viram numa posição contrária à maioria dos norte-americanos, no que diz respeito à Guerra Civil Espanhola. Crosby explica que a Igreja se posicionou ao lado de Franco e denunciou as perseguições conduzidas pelos legalistas aos católicos naquele país. Além disso, para muitos conservadores católicos, o apoio que muitos liberais americanos deram aos republicanos (legalistas) pareceu confirmar a crença de que liberalismo e comunismo eram a mesma coisa.

A retórica de oposição ao liberalismo e de solidariedade aos católicos perseguidos sob os regimes comunistas foi marca do catolicismo norte-americano que já havia se manifestado nos anos 20 (denúncia de perseguições no México), nos anos 30 (denúncias sobre a Espanha), e que ganhou força no período pós-Segunda Guerra. Frank questiona, em seu artigo, porque nos anos 30 os católicos estavam mais preocupados com o perigo comunista do que os não-católicos, e responde com base nos ensinamentos das encíclicas Rerum Novarum (1891) e Divini Redemptoris (1937). Mostra que a condenação ao liberalismo estava inscrita nas duas cartas papais no sentido de que o liberalismo irreligioso e imoral gerava individualismo, que gerava socialismo, 
que gerava comunismo. Esses perigos não eram percebidos pelos não-católicos que não tinham posições críticas ao liberalismo.

No que se refere a perseguições contra católicos, o tema que não era novo ganhou força depois da Segunda Guerra, quando a atenção se voltava para os países ocupados pela União Soviética. Exemplo disso são mobilizações acontecidas nos Estados Unidos em honra a alguns bispos transformados em mártires, como o arcebispo Aloysius Stepinac da Yugoslávia, que foi condenado pelo regime de Tito a 16 anos de prisão, e o cardeal da Hungria, Joseph Mindszenty, preso em dezembro de 1948, julgado e condenado por traição, subversão e espionagem. Foi condenado à morte, mas depois a pena foi comutada por prisão perpétua.

Em 1950, a pior parte da perseguição dos regimes comunistas à Igreja havia acabado, mas a imprensa católica norte-americana se portava como se as perseguições continuassem. Nos Estados Unidos, a principal liderança da Igreja, o cardeal Francis Spellman, arcebispo da diocese de Nova Iorque, dirigia freqüentemente suas preocupações aos destinos dos católicos nos países da "cortina de ferro", mas também se voltou para o problema da subversão comunista nos Estados Unidos e deu forte apoio ao macartismo. Outro líder de destaque foi o bispo Fulton J. Sheen, assistente de Spellman em Nova Iorque. Vinte anos antes de McCarthy aparecer, Sheen — por meio de livros, artigos, panfletos, sermões e discursos - já denunciava o comunismo em oposição ao catolicismo romano.

Fulton Sheen, conforme relata Robert Ellwood em Korea, Catholics, Protestants and Anticommunism, tinha desde os anos 30 um programa na rádio NBC chamado Hora Católica e dava cursos para convertidos ao cristianismo. Escreveu livros que se tornaram best-sellers como Peace of Soul, de 1949. Nos anos 50, apresentou um programa na televisão que chegou a ter dois milhões de telespectadores. Ele é representado pelo autor como o porta-voz da versão católica do American way of life $e^{21}$.

Os autores que estudam o anticomunismo católico norte-americano chamam a atenção para as divergências que o tema provocava dentro da Igreja, mostrando a existência de um grupo "conservador" e outro "progressista". No primeiro, estariam situados os bispos antes citados, alguns periódicos como o Our Sunday Visitor e o Brooklyn Tablet, além de grupos de leigos ativistas como os Catholic War Veterans e os Knights of Columbus. Estes últimos realizavam atividades como piquetes, protestos em ocasiões de visitas de russos, pressão para vigilância sobre os funcionários públicos, boicotes a cinemas e teatros que apresentassem filmes ou peças portadoras de indícios do comunismo ateu, produção de panfletos, etc. Também realizavam programas educacionais, com cursos e programas de rádio. Participando do esforço também estava uma agência de notícias da Igreja que supria os jornais diocesanos. 
Os católicos progressistas, por sua vez, criticavam o anticomunismo dos conservadores por achá-lo antidemocrático, monolítico e conspiratório. Acreditavam que se fossem eliminados a pobreza e o sofrimento, os comunistas não teriam onde atuar. O combate ao comunismo, então, não deveria se basear numa "caça às bruxas" e numa legislação repressiva, mas sim na expansão de programas sociais, com base nas encíclicas Rerum Novarum e Quadragesimo Anno. Esses católicos se viam representados em publicações como Commonweal e America. Alguns deles atuavam no sindicalismo e havia entre eles alguns "padres operários".

No entanto, a maior parte da liderança católica pertencia ao campo conservador e o mesmo acontecia com as organizações de leigos e com os periódicos católicos. As disputas entre os dois grupos parecem ter tido como protagonistas editores de jornais, escritores, líderes políticos, diretores de organizações leigas, lideranças do clero. Os leigos, segundo Crosby, participaram esporadicamente ou olharam o processo de uma maneira passiva.

O conflito interno tocava num tema político de peso: o amor à pátria. Nesse sentido, tanto os classificados como conservadores quanto os chamados de progressistas faziam insistentes apelos ao patriotismo. No início da década de 1950, amor à pátria significava para uns a aceitação irrestrita da cam476 panha do senador McCarthy. Ele estaria, sozinho, atacando as raízes daquilo que ameaçava a América, o comunismo ateu. Para outros, amor à pátria se manifestava na denúncia de que McCarthy estaria ameaçando os procedimentos democráticos que estavam no coração do sistema americano.

$O$ peso do patriotismo nas posturas a respeito do anticomunismo permite que este seja encarado como uma "religião civil". É o que se vê na análise realizada por Crosby. O autor chega a essa formulação após comentar algumas pesquisas sobre hábitos de leitura entre católicos, as quais sugerem que a influência que a Igreja tinha no dia-a-dia dos seus fiéis era pequena, já que a maioria deles restringia sua vida religiosa às "tarefas do domingo". Os leigos estariam prestando pouca atenção aos posicionamentos do papa sobre capitalismo, paz, erros modernos, bem como para os pronunciamentos dos bispos em matérias semelhantes. De acordo com o raciocínio do autor, se os católicos norte-americanos definiam seus compromissos com a Igreja de forma tão restrita - como "coisas de domingo"- e assim não estavam tão abertos à influência do catolicismo, eles teriam sido persuadidos muito mais por uma "religião civil". Essa conclusão parece estar diretamente ligada à hipótese que o autor defende: a de que os católicos não foram significativamente mais anticomunistas ou mais favoráveis a McCarthy do que os não-católicos, e que as raízes do conservadorismo estariam menos nos ensinamentos da Igreja do que na cultura política norte-americana. De qualquer forma, o conceito de 
religião civil que o autor utiliza parece ser bastante fecundo para a análise do anticomunismo norte-americano. O conceito foi tomado de Robert Bellah.

A religião civil seria, segundo Bellah, todo um corpo de crenças religiosas e valores morais que envolve a vida norte-americana, com o qual a maioria da população concorda e o qual tem lugar de destaque na retórica política: a crença de que Deus chamou os Estados Unidos para serem um "novo Israel"; de que Ele estará com o país até o julgamento final, o qual será muito severo; as noções de democracia, liberdade individual e pluralismo religioso; a tese de que Deus fez os Estados Unidos como um exílio para os oprimidos; e, finalmente, a doutrina de que Deus fez, na América, todos os homens iguais e deu a todos uma chance igual num novo país que deveria servir como exemplo diante do resto do mundo. A era de McCarthy viu uma renovação e intensificação dessa religião civil ${ }^{22}$.

Elementos semelhantes aparecem na análise de Ellwood, que vê o americanismo como uma "religião de Estado" ${ }^{23}$. No começo dos anos 50, segundo este autor, era senso comum que o anticomunismo deveria estar em primeiro lugar em qualquer decisão política doméstica ou internacional. No plano doméstico, a política assumiu o lado negro da religião com a caça às bruxas e a exclusão dos "contaminados". Esta espécie de anticomunismo religioso, como uma visão abrangente de mundo, um tipo de "igreja de Estado", também chamado de "americanismo", teve seu pico no início dos anos 50.

$\mathrm{O}$ americanismo tinha como certo que o comunismo não era apenas um desafio político, militar e econômico, mas também espiritual, pois ameaçava os fundamentos da vida humana, a relação da alma com Deus. A América ideal aparecia como unificada espiritualmente, uma nação temente a Deus na qual os que quebrassem a unanimidade deveriam ser expelidos para o bem da comunidade.

No que se refere especificamente ao macartismo, difundiu-se pelo país a crença de que a Igreja Católica estava por trás da campanha do senador. Para desconstruir tal idéia, Vincent De Santis mostra, em American Catholics and McCarthyism, exemplos de posicionamentos contrários e favoráveis ao senador, na hierarquia, na imprensa católica, em grupos organizados de leigos, e entre católicos que responderam a pesquisas de opinião. De Santis defende que a Igreja não tinha uma posição oficial sobre McCarthy e que ela estava dividida entre os que o apoiavam e os que o condenavam, apesar do número dos primeiros ser maior que o dos segundos; e apesar da maioria dos que se expressavam publicamente ser favorável ao senador.

No caso da hierarquia, o autor faz saber que o único bispo que combateu publicamente o macartismo foi o bispo auxiliar de Chicago, Bernard J. Sheil. Este bispo defendia um "anticomunismo afirmativo", incluindo a salvaguarda dos procedimentos democráticos, a diferenciação entre traição e não- 
conformidade, o apoio a medidas militares para resistir à intimidação comunista e a percepção de que os Estados Unidos não ofereciam ambiente para o crescimento do comunismo. O oposto teria sido o exemplo do cardeal Spellman, que deu apoio a McCarthy, fazendo com que o macartismo fosse respeitável e aceitável ${ }^{24}$. Enfatizou em seus discursos a ameaça da infiltração comunista nos Estados Unidos e da destruição da Igreja no exterior. Foi freqüentemente convidado para dar entrevistas em programas de rádio, como aqueles que os Knights of Columbus transmitiam para 226 estações, ao longo do ano de 1947.

John Cooney fez em The American Pope um estudo sobre o cardeal, considerado o "capelão da Guerra Fria", no qual comenta as vantagens e desvantagens de posicionamentos como os assumidos por Spellman:

Em qualquer lugar onde falava, Spellman reforçava sua imagem como um defensor tanto do catolicismo quanto do americanismo. Ele fazia votos de que os dois não fossem mais vistos como se excluindo mutuamente, acusação feita contra a Igreja nos Estados Unidos, desde muito tempo. De fato, para muitas pessoas, o catolicismo passou a ser identificado com a 'Cruzada Vermelha' de Spell$\operatorname{man}^{25}$.

Tendo apresentado esses elementos sobre o anticomunismo católico norte-americano, o passo seguinte é realizar algumas comparações com as formas que o anticomunismo católico assumiu no Brasil, na mesma época.

\section{ANTICOMUNISMO CATÓlico NO BRASIL E NOS Estados Unidos}

Se já na segunda metade do século XIX, o tema do comunismo freqüentava as encíclicas papais, no Brasil, o anticomunismo parece ter tido sua fase inicial entre 1917 e $1930^{26}$. Seus alvos eram movimentos operários de inspiração anarquista, socialista e, mais tarde, comunista. Nesse quadro, as preocupações da Igreja se dirigiam tanto ao perigo representado pela subversão e "materialização" do operariado quanto para a disseminação do laicismo entre as elites letradas e ao empenho de convencer os governantes que o Brasil era, acima de tudo, um país católico.

Nos anos 20, a formação religiosa das elites governantes foi uma das preocupações da Igreja, levada adiante com o desenvolvimento de uma literatura especializada e com a criação de centros de estudo e grupos de leigos engajados. Merece destaque a criação da revista A Ordem, em 1921, e do Centro D. Vital, dirigido este por leigos que se destacariam como intelectuais católicos, como Jackson de Figueiredo e Alceu Amoroso Lima. Num estudo sobre a re- 
vista A Ordem, Mônica Veloso mostrou que vários dos elementos enfocados nela eram integrantes da oposição mais geral entre os ideais cristãos e o liberalismo. Aí estaria clara uma das características do anticomunismo católico: a filiação do comunismo ao liberalismo. Segundo a autora, "é a partir da denúncia do Estado liberal que se articula o combate ao comunismo (...). O Estado liberal, enquanto expressão do poder político burguês, contém em si os elementos que fatalmente conduzirão ao comunismo" ${ }^{27}$.

Apesar das constantes queixas católicas relacionadas à perda do status de religião oficial no Brasil, estudos mais específicos sobre a atuação do episcopado têm demonstrado a proximidade das lideranças católicas com os grupos no poder em diversos Estados brasileiros, durante a República Velha ${ }^{28}$. A década de 1930, por sua vez, iniciou trazendo boas perspectivas para a hierarquia católica, no que se refere ao reconhecimento da Igreja pelos governantes e pela população em geral. Um exemplo disso foi o resultado da ampla campanha realizada pela Liga Eleitoral Católica (LEC) ${ }^{29}$. Ela visava congregar o eleitorado católico, selecionar candidatos que se comprometessem com os princípios sociais católicos, candidatos estes que teriam o aval da entidade. Tais princípios eram basicamente o ensino religioso facultativo, a indissolubilidade do casamento, a assistência religiosa às Forças Armadas, a liberdade sindical, a defesa da propriedade, o combate a atividades subversivas. O trabalho da liga se dava através do alistamento de eleitores, chamando também a atenção para a importância do voto feminino; da apresentação das propostas aos candidatos; e da publicação na imprensa da lista daqueles que haviam se comprometido com tais propostas. Praticamente todas as propostas da LEC foram contempladas na Constituição de 1934. Candidatos que não assumissem a oposição ao comunismo não poderiam ser indicados pela liga. Em eleições seguintes, a LEC continuou assumindo a função de orientar o voto do eleitorado católico e de preveni-lo contra o perigo comunista.

$\mathrm{O}$ anticomunismo católico também esteve relacionado com a "descoberta”, pela Igreja, da questão operária no Brasil, que também se deu nos anos 30 e se corporificou nos Círculos Operários ${ }^{30}$. Com base na encíclica Rerum Novarum de Leão XIII (1891) e da retomada da mesma em 1931 com a Quadragessimo Anno, setores da Igreja passaram a se preocupar com o peso crescente da classe operária no País. A "questão operária" passou a ser interpretada pela Igreja dentro da óptica da necessidade de colaboração e harmonia entre as classes, combatendo assim as "ideologias exóticas" e contribuindo com o governo na regulamentação das relações entre patrões e operários, dentro de um espírito corporativo. Os círculos desenvolviam atividades de educação, lazer, saúde entre os operários e seus familiares. Visavam, entre outras coisas, criar líderes sindicais imbuídos da doutrina social da Igreja que pudessem concorrer com os comunistas e esquerdistas em geral. 
Mas a década de 1930 também foi marcada pela repercussão do levante de 1935, que ficou conhecido como Intentona Comunista. Assim como outras instituições brasileiras, a Igreja dirigiu seus ataques aos "traidores" da Pátria e ao perigo que eles representavam para o Brasil. Além disso, repercutiram no mundo católico brasileiro as denúncias a respeito de perseguições religiosas na Espanha, durante a Guerra Civil. Ao mesmo tempo deu-se a recepção e divulgação da encíclica de Pio XI, que versava exclusivamente sobre o comunismo, a Divini Redemptoris, escrita em 1937.

No período posterior ao Estado Novo, o anticomunismo católico se manifestava em discursos sobre os perigos que poderiam acompanhar a liberdade política então instaurada. Mesmo que algumas críticas começassem a ser dirigidas ao capitalismo, aquelas voltadas ao comunismo eram muito mais insistentes, pois "tratava-se agora para os bispos, de tatear nas novas sendas, inseguras, da redemocratização que soltava as massas, sobretudo as urbanas, ao jogo livre das disputas partidárias e à livre circulação de idéias" ${ }^{31}$.

Do início dos anos 50 até o golpe de 1964, alguns setores da Igreja Católica no Brasil — ligados à direção da Conferência Nacional dos Bispos do Brasil (CNBB) e a grupos de Ação Católica — passaram a assumir posições de apoio a lutas populares, o que fez com que as críticas ao comunismo ou a determinados aspectos do capitalismo (como o laicismo e a secularização) dessem lugar ao questionamento das injustiças sociais. Estava surgindo, nesse momento, uma espécie de esquerda católica que, todavia, ocupava posições não-majoritárias dentro da instituição, a qual se mantinha como atuante batalhadora contra o comunismo.

No início da década de 1960, o propósito de uns de combater o comunismo e de outros de romper com as estruturas injustas se manifestou na atuação da Igreja no processo de sindicalização dos trabalhadores rurais. Já na década anterior, uma série de iniciativas visava contribuir para a melhoria da situação dos trabalhadores do campo, retirando assim os motivos para a difusão de idéias subversivas ${ }^{32}$. Movidos pelas possibilidades abertas pelo Estatuto do Trabalhador Rural e pelo temor do comunismo, localizado especialmente nas Ligas Camponesas, católicos de diversos Estados do Brasil criaram Frentes Agrárias. No Rio Grande do Sul, por exemplo, foi criada em 1961 a Frente Agrária Gaúcha (FAG), através da qual foram organizados muitos sindicatos de trabalhadores rurais.

Vê-se, então, que ao longo do século XX, o combate ao comunismo foi um dos ingredientes do discurso e da prática da Igreja Católica no Brasil. Visava combater uma série de manifestações identificadas ao comunismo, da mesma forma que permitia à Igreja reservar um espaço importante de participação na discussão dos rumos políticos do País. O trabalho de comparação com o anticomunismo católico norte-americano permitirá levantar novos ele- 
mentos sobre o brasileiro. A comparação será feita em torno de cinco temas: o lugar da religião católica em cada um dos países e a relação disso com o anticomunismo; a exploração do tema da perseguição à Igreja no México, na Espanha e nos países sob a "cortina de ferro"; as clivagens dentro da Igreja em ambos os países no que se refere ao anticomunismo; a recepção do anticomunismo católico; e finalmente, uma breve menção às sociedades nas quais, no período pós-guerra, esses católicos brasileiros e os norte-americanos viviam.

No que diz respeito ao lugar ocupado pela religião católica em cada um dos países, deve-se lembrar que até a Proclamação da República o catolicismo era a religião oficial do País. Pode-se também afirmar que no Brasil os católicos sempre foram a maioria da população. Mesmo depois da separação entre Estado e Igreja, essa manteve uma posição social e um peso político muito grandes. Ela não tinha competidores à sua altura e mesmo as críticas inspiradas no positivismo não tiveram força para marginalizá-la. Desde o final do século XIX, a Igreja Católica no Brasil conseguiu se adaptar aos novos tempos, se reorganizar, promover importantes reformas internas, e manter-se como interlocutora importante nas esferas decisórias do País ${ }^{33}$.

Se, no Brasil, ser católico fazia parte da "normalidade", nos Estados Unidos isso era uma marca do ser "diferente". O número relativamente pequeno de católicos comparado com o conjunto da população, a opção por certas posturas de isolamento e as desconfianças provenientes das igrejas protestantes contribuíram para que os católicos norte-americanos se sentissem obrigados a buscar formas de reconhecimento e aceitação, especialmente de aceitação como cidadãos zelosos pela sua pátria. Como foi visto acima, o combate ao comunismo acabou assumindo tal função. Assim, para ser ao mesmo tempo bom católico e bom cidadão norte-americano era preciso ser anticomunista.

No caso do Brasil, o discurso católico — mas não apenas ele — também apelava para as ligações entre catolicismo, patriotismo e anticomunismo. Mas a combinação era diferente daquela que ocorria nos Estados Unidos. Aqui ela visava mostrar que sendo o Brasil um país com uma forte tradição católica (ou em termos mais amplos, um país cristão), isso tornava infrutíferas as propostas comunistas que tentassem ser colocadas em prática aqui. Ter nascido num país com tão fortes tradições católicas era uma espécie de salvaguarda contra o "vírus" comunista. Dessa forma, o "bom brasileiro" — que é católico — teria grandes chances de ser anticomunista. Os que professassem a doutrina dos "vermelhos" seriam considerados traidores da pátria, defensores de ideologias exóticas e, conseqüentemente, maus brasileiros. Mas é importante lembrar que a necessidade de, especialmente nos anos 50, se mostrar um bom cidadão ou um bom patriota, foi muito mais intensa nos Estados Unidos do que no Brasil.

O tema da perseguição à Igreja no México, na Espanha e nos países co- 
munistas fazia parte das campanhas anticomunistas desenvolvidas pelos católicos tanto nos Estados Unidos quanto no Brasil. Nos Estados Unidos, esse era um tema que havia feito com que, ainda nos anos 20 e depois nos 30, grupos ativistas de católicos se colocassem contra o governo norte-americano e contra parte significativa da opinião pública, como se viu anteriormente. Entrevistas realizadas por mim com membros do clero católico no Rio Grande do Sul mostraram que entre as memórias sobre o medo do comunismo que estas pessoas trazem até hoje havia um lugar importante para as lembranças relacionadas à perseguição que a Igreja sofrera no México e na Espanha. Mesmo que tal perseguição não tivesse sido efetuada por governos comunistas, é assim que ela aparece nos relatos dessas pessoas ${ }^{34}$.

As razões dessa associação podem ser buscadas no processo educacional conduzido por padres jesuítas que estiveram à frente de vários seminários católicos no Rio Grande do Sul e que incentivavam, nos jovens aspirantes ao sacerdócio, a leitura de obras a respeito de perseguições e martírios sofridos por membros da Igreja, entre eles, pelos próprios jesuítas. Entre essas histórias havia um lugar de destaque para o caso do padre Miguel Pró, fuzilado no México em 1927 e que se tornou uma espécie de mártir católico ${ }^{35}$. Esse jesuíta permanece na memória de alguns padres entrevistados como um mártir da luta contra o comunismo.

Para entender essa relação feita pelos católicos entre a perseguição à Igreja no México e o comunismo, é preciso também lembrar que esta foi uma estratégia adotada pelo Vaticano ao longo da década de 1930, no contexto da Guerra Civil Espanhola. Aos poucos, a tríade Rússia, México e Espanha passou a figurar nas encíclicas papais que combatiam o comunismo, especialmente na Divini Redemptoris, de 1937. Esta encíclica trata dos casos de perseguição à Igreja, entendendo-os como uma das conseqüências da aplicação da doutrina comunista, a qual seria difundida por meio de propaganda bem organizada e sedutora e teria seu caminho preparado pelo liberalismo. Como se vê no trecho abaixo, o nome do México aparece ao lado daquele da Rússia:

(...) Onde quer que os comunistas conseguiram radicar-se e dominar - e aqui pensamos com particular afeto paterno nos povos da Rússia e do México — aí, como eles próprios abertamente o proclamam, por todos os meios se esforçaram por destruir radicalmente os fundamentos da religião e da civilização cristãs, e extinguir completamente a sua memória no coração dos homens, especialmente da juventude. Bispos e sacerdotes foram desterrados, condenados a trabalhos forçados, fuzilados ou trucidados de modo desumano; simples leigos tornados suspeitos por terem defendido a religião, foram vexados, tratados como inimigos, e arrastados aos tribunais e às prisões ${ }^{36}$. 
Pio XI também se refere à Espanha, na seqüência do acima exposto. "Não é esta ou aquela igreja destruída, este ou aquele convento arruinado; mas, onde quer que lhes foi possível, todos os templos, todos os claustros religiosos, e ainda quaisquer vestígios da religião cristã [...]. E não se limitou o furor comunista a trucidar bispos e muitos milhares de sacerdotes, religiosos e religiosas [...] mas fez um número muito maior de vítimas em leigos de todas as classes." Assim, um tema que foi objeto de atenção do papa teve amplas repercussões entre católicos dos Estados Unidos e do Brasil. No último caso, o tema comparece mais na memória de membros do clero do que na dos leigos e mesmo na literatura produzida pela Igreja.

Outro elemento de comparação são as clivagens que se manifestaram dentro da Igreja em ambos os países, no que se refere ao anticomunismo. Os textos aqui utilizados defendem que as divergências entre os católicos "conservadores" e os "progressistas" foram intensas nos Estados Unidos. Em alguns artigos, escritos por autores ligados à Igreja e/ou publicados em revistas que de alguma forma revelam o mesmo perfil, percebe-se uma ênfase na questão da divisão havida entre os católicos em relação ao macartismo. Essa parece ser uma estratégia para responder às acusações da Igreja ter apoiado o senador e sua caça às bruxas, acusação que sobreviveu à queda de McCarthy.

Parece que a necessidade de se libertar do rótulo de macartista fez com que alguns historiadores católicos passassem a enfatizar as divergências entre católicos progressistas e conservadores, apesar de admitirem que os segundos eram em maior número e suas posições tinham maior publicidade que a dos progressistas. É o caso do texto já citado de Robert Frank, que faz um esforço grande para defender a hipótese de que não havia uma posição oficial da Igreja a favor de McCarthy. Contudo, o conjunto dos dados empíricos que o autor apresenta dificilmente permite que o leitor acredite na hipótese. De qualquer forma, e levando em conta as evidências trazidas pelos textos citados, parece que nos Estados Unidos a divisão entre "direita" e "esquerda" na Igreja se manifestou num período anterior ao que aconteceu no Brasil. Ela teria se manifestado já na primeira metade dos anos 50 , sendo contemporânea do macartismo.

No caso brasileiro, a historiografia mostra que foi no final dessa década de 1950, e especialmente no início da seguinte que surgiram, dentro da Igreja, experiências que diferiam significativamente das tradicionais. Eram ações levadas adiante pela Ação Católica, especialmente através da JUC, JEC e JOC, em atividades voltadas à sindicalização rural, à luta contra o analfabetismo, à participação no movimento estudantil, à preocupação com os problemas causados pela estrutura agrária brasileira e pela necessidade da reforma agrária; ou ainda aquelas patrocinadas pela CNBB, criada em 1952, e que teve papel decisivo na abertura de espaço para que grupos com idéias progressistas pudessem ter atuação e espaço dentro da Igreja ${ }^{37}$. 
Outro elemento de comparação diz respeito à recepção do anticomunismo católico. A historiografia sobre o catolicismo nos Estados Unidos que foi aqui analisada tende a situar as disputas anticomunistas ao nível das lideranças católicas. Outros historiadores trazem indícios de que a população imersa na cultura da Guerra Fria podia não se sentir tão afetada ou mobilizada pelo anticomunismo, podia ter dúvidas ao explicar o que era o comunismo, poderia trazer marcas do temor em relação a ele, mas também poderia ter passado por aquela época preocupando-se com outras coisas.

Um exemplo disso é trazido por Peter Filene, num artigo que descreve uma experiência feita com noventa estudantes de graduação em História ${ }^{38}$. Os jovens foram desafiados a questionar seus avós sobre os problemas causados pelo clima de caça às bruxas do final dos anos 1940 e da década seguinte. Os resultados foram surpreendentes, pois os avós revelaram que não chegaram a se sentir profundamente perturbados com a agressão comunista na Europa Oriental e Coréia, nem sentiram a paranóia do anticomunismo e do macartismo. As preocupações maiores destes indivíduos - quando estavam em seus 20 e poucos anos - eram as de manter o emprego, pagar o aluguel e criar os filhos.

Algo semelhante é descrito por Joel Kovel. Ele se refere a uma pesquisa feita em 1955, no auge do "medo vermelho", por Samuel Stouffer, que concluiu que menos de um por cento dos norte-americanos estava realmente preocupado com uma tomada do poder pelos comunistas. Outro exemplo citado pelo mesmo autor é aquele de um repórter do Capitol Times, de Madison, Wisconsin, que em 1953 recebeu as seguintes respostas para a pergunta: O que, na sua opinião, é um comunista?

"Eu não sei, eu sou um cidadão americano."

"Bem, eles estão sempre se despistando... Eu não sei muito sobre eles."

"Eu não tenho certeza - a definição parece estar mudando."

"Um criminoso, eu acho."

"Uma pessoa que quer guerra."

"Eu tenho tentado descobrir, mas não consegui chegar a uma definição" ${ }^{39}$.

Esses exemplos, juntamente com a constatação de Crosby de que os católicos não atentavam muito para os ensinamentos da Igreja, como foi comentado acima, abrem espaço para que se questione a recepção e a eficácia do anticomunismo fora do grupo formado pelo alto clero e pelos intelectuais católicos.

Pude constatar algo semelhante em entrevistas realizadas com católicos no Rio Grande do Sul, ao longo da pesquisa de doutorado. Na memória desses indivíduos ficaram registrados o caráter maléfico do comunismo e também seus principais alvos: a família, a religião, a propriedade. Parte deles lem- 
brou ter sentido medo do comunismo, outros lembraram do que se falava a respeito, mas afirmaram não terem sentido medo. A maior parte deles e delas revelou dificuldades em se expressar sobre o tema, não conseguindo explicar o que era o comunismo ou lembrando de não ter clareza sobre isso no passado. Em muitos casos, a estratégia para resolver tais dificuldades foi a de relacionar o medo do comunismo ao medo sentido em outras situações como no período da Segunda Guerra, na campanha de nacionalização do Estado Novo, em lembranças ou vivências a respeito de movimentos armados locais ou nacionais.

$\mathrm{O}$ comunismo se apresentou como algo distante. Ele poderia estar situado na Rússia ou em países onde a Igreja era perseguida, como no México e na Espanha. Configurava-se especialmente na figura de Luiz Carlos Prestes. Parecia não ter outros representantes no País, no Estado ou nas localidades onde as pessoas moravam. O rótulo de comunista poderia, às vezes, ser utilizado para designar inimigos políticos ou pessoais ou ainda para se referir a pessoas com posicionamentos anticlericais.

É claro que as sociedades nas quais, no período pós-guerra, esses católicos brasileiros que foram entrevistados e os norte-americanos (sobre os quais se sabe através da historiografia) viviam eram muito diferentes uma da outra. A sociedade norte-americana da Guerra Fria estava marcada por um enorme surto de prosperidade, por uma forte e organizada presença do anticomunismo, pela multiplicidade de veículos pelos quais o combate ao comunismo era divulgado, pelo revivecimento da crença na religião e por uma pressão muito grande para se posicionar a respeito deste tema. Os católicos brasileiros entrevistados nasceram, em sua maioria, na zona rural, tinham dificuldade de acesso a meios de comunicação como rádio e jornal, tinham poucos anos de escolaridade. Mas, mesmo se se pensar em católicos brasileiros que na década de 1950 viviam em centros urbanos, com possibilidades de maior acesso a informações sobre comunismo e anticomunismo, ainda assim é preciso lembrar que a "máquina" anticomunista brasileira era menos organizada e possivelmente menos "eficaz" que a norte-americana. Eram diferentes as configurações do anticomunismo em cada um desses países, com especificidades no tipo de organização, leis, sistemas de repressão e propaganda, grupos de ativistas, etc.

Mesmo que houvesse orientações comuns emanadas de Roma - através das encíclicas, por exemplo - o anticomunismo católico precisava se adaptar ao lugar que os católicos ocupavam em cada sociedade, ao lugar que a instituição ocupava ante os poderes constituídos, à relação dela com outros grupos ou instituições que também combatiam o comunismo, à intensidade de tal combate e à forma como ele funcionava. Precisava especialmente se adaptar às diferentes combinações entre as posturas e práticas a respeito do capitalismo, do liberalismo e do comunismo. 


\section{NOTAS}

${ }^{1}$ Professora do Departamento de História da Universidade Federal do Rio Grande do Sul.

${ }^{2}$ Trata-se da tese de doutorado: Memórias e avaliações: norte-americanos, católicos e a recepção do anticomunismo brasileiro entre 1945 e 1964. Porto Alegre: UFRGS, 2002. A elaboração da tese - sob orientação da Prof ${ }^{\mathrm{a}}$. Dr. ${ }^{\mathrm{a}}$ Sandra Jatahy Pesavento - contou com o apoio financeiro do CNPq e com uma bolsa de doutorado sanduíche patrocinada pela Capes e pela Comissão Fulbright. O doutorado sanduíche foi realizado na University of Maryland, College Park, MD, Estados Unidos, com a orientação da professora Bárbara Weinstein.

${ }^{3}$ FERREIRA, José Roberto Martins. Os novos bárbaros: análise do discurso anticomunista do Exército brasileiro. São Paulo: PUCSP, 1986. Dissertação de Mestrado em Ciências Sociais; DUTRA, Eliana de Freitas. O ardil totalitário: imaginário político no Brasil dos anos 30 . Rio de Janeiro: Ed. UFRJ, 1997; AZEVEDO, Débora Bithiath de. Em nome da ordem: democracia e combate ao comunismo no Brasil (1946-1950). Brasília: UnB, 1992. Dissertação de Mestrado em História; MOLINARI FILHO, Germano. Controle ideológico e imprensa: o anticomunismo n'O Estado de S. Paulo (1930-1937). São Paulo: PUCSP, 1992. Dissertação de Mestrado em História; CANCELLI, Elizabeth. O mundo da violência: a polícia da era Vargas. Brasília: Editora da UnB, 1994; RODEGHERO, Carla Simone. O diabo é vermelho: imaginário anticomunista e Igreja Católica no Rio Grande do Sul (1945-1964). Passo Fundo: Ediupf, 1998; MARIANI, Bethania. O PCB e a imprensa. Os comunistas no imaginário dos jornais (1922-1989). Rio de Janeiro: Revan, 1998; SILVA, Carla Luciana. Perigo vermelho e ilusão comunista: configurações do anticomunismo brasileiro — da Aliança Liberal à Aliança Nacional Libertadora. Porto Alegre: PUCRS, 1998. Dissertação de Mestrado em História; SÁ MOTTA, Rodrigo Patto. Em guarda contra o "perigo vermelho": o anticomunismo no Brasil (1917-1964). São Paulo: USP, 2000. Tese de Doutorado em História.

${ }^{4}$ RODEGHERO, Carla Simone. O diabo é vermelho... Op. cit.

${ }^{5}$ RODEGHERO, Carla Simone. Memórias e avaliações... Op. cit.

${ }^{6}$ WHITFIELD, Stephen J. The Culture of the Cold War. 2.ed. Baltimore/ London: The Johns Hopkins University Press, 1996, p. 53.

${ }^{7} I d e m$, p. 56.

${ }^{8}$ KUZNICK, Peter J. e GILBERT, James. Rethinking Cold War Culture. Washington, D.C.: Smithsonian Institution Press, 2001, p. 11.

${ }^{9}$ WHITFIELD, Stephen J. Op. cit., p. 11.

${ }^{10}$ De acordo com FARIELLO, Griffin. Principal Federal Heresy Tribunals and Laws. In: Red Scare: Memories of the American Inquisition: an Oral History. New York/ London: W.W. Norton \& Company, 1995, pp. 17 a 19, e ARMS, Thomas S. Encyclopedia of the Cold War. New York: Facts on File, 1994, pp. 286-7.

${ }^{11}$ WHITFIELD, Stephen. Op. cit., p. 11.

${ }^{12}$ De acordo com HEALE, M. J. McCarthy's Americans: Red Scare Politics in State and Nation - 1935-1965. Athens: The University of Georgia Press, 1998, pp. 278-9 e KOVEL, Joel. Red Hunting in the Promised Land: Anti-communism and the Making of America. London/ Washington DC: Cassel, 1997. 
${ }^{13} \mathrm{O}$ termo New Deal é usado para descrever o programa do presidente Roosevelt para lidar com os efeitos da Grande Depressão entre 1933 e 1939. Visava restaurar a confiança pública e aliviar a situação de 14 milhões de desempregados. O programa foi marcado por uma série de ações intervencionistas do Estado na economia. De acordo com PALMOWSKI, Jan. A Dictionary of Twentieth Century World History. Oxford: Oxford University Press, 1997, p. 441. O termo New Fair Deal, que será mencionado a seguir, se refere ao programa doméstico de Truman lançado em janeiro de 1949. Ele pretendia ir além do New Deal, introduzindo medidas relativas a direitos civis, práticas justas de emprego, educação, assistência pública à saúde, extensão dos benefícios de seguridade social, apoio para programas de habitação para pessoas com salários menores, controle de preços e aluguéis e subsídios à agricultura. Também propôs emprego para todos e aumento do salário mínimo. A maioria das medidas foi bloqueada no Congresso por republicanos e por democratas conservadores. De acordo com a mesma fonte, p. 198.

${ }^{14}$ Esse tema é analisado na obra de WHITE, John Kenneth. Still Seeing Red: How the Cold War Shapes the New American Politics. Boulder, CO: Westview Press, 1998.

${ }^{15}$ Alguns exemplos do que tem sido escrito: LIEBERMAN, Robbie. The Strangest Dream: Communism, Anticommunism and the U.S. Peace Movement (1945-1963). New York: Syracuse University Press, 2000; BUCKINGHAN, Peter H. America Sees Red: Anticommunism in America: 1870-1980. A guide to issues and references. Claremont, CA: Regina Books, 1988; HAYNES, John Earl. Red Scare or Red Menace? American Communism in the Cold War era. Chicago: Ivan R. Dee, 1995; PARENTI, Michael. Blackshirts \& Reds: Rational Fascism and the Overtrow of Communism. San Francisco, CA: City Ligth Book, 1997; e os já citados HEALE, M. J. McCarthy's Americans e FARIELLO, Griffin. Red Scare: Memories of the American Inquisition.

${ }^{16}$ Este relato baseia-se em: KLINGAMAN, William K. Encyclopedia of the McCarthy Era. New York: Facts on File, 1996, pp. 253 a 260.

${ }^{17}$ HEALE, M. J. Op. cit., p. 297.

${ }^{18}$ WHITFIELD, Stephen. Op. cit., p. 83.

${ }^{19}$ Os trabalhos utilizados para esta análise do anticomunismo católico norte-americano são os que seguem: FRANK, Robert. Prelude of the Cold War: American Catholics and Communism. In: Journal of Church and State, vol. 34, $\mathrm{n}^{\circ} 1$, inverno 1992, pp. 39-56; DE SANTIS, Vincent. American Catholics and McCarthyism. In: The Catholic Historical Review. Vol. LI, Abril, 1965, n 1, pp. 1-30; CROSBY, Donald F. God, church, and flag. Chapel Hill: The University of North Carolina Press, 1978; ELLWOOD, Robert S. Korea, Catholics, Protestants, and Anticommunism. In: The Fifties Spiritual Marketplace: American Religion in a Decade of Conflict. New Brunswick, N.J: Rutgers University Press, 1997, pp. 27 a 62; RICHET, Isabelle. Vade Retro Satana! Les églises et la chasse aux sorcières. In ROUGÈ, Jean-Robert. L'Anticommunism aux États-Unis de 1946 à 1954. Paris: Presses de l'Université de Paris-Sorbonne, 1995, pp. 151-173.

${ }^{20}$ CROSBY, Donald. Op. cit., p. 244.

${ }^{21}$ ELLWOOD, Robert S. Op. cit., p. 50.

${ }^{22}$ CROSBY, Donald. Op. cit., p. 205.

${ }^{23}$ ELLWOOD, Robert S. Op. cit. 
${ }^{24}$ De acordo com COONEY, John. The American Pope: The Life and the Times of Francis Cardinal Spellman. New York: Time Books, 1984. O autor diz que depois que Kennedy foi eleito presidente — contra a vontade de Spellman — o cardeal perdeu o posto de personalidade católica com mais destaque no país.

${ }^{25}$ Idem, p. 154.

${ }^{26} \mathrm{O}$ relato sobre a trajetória do anticomunismo católico no Brasil está baseado em meus dois trabalhos antes citados: $O$ diabo é vermelho e Memórias e avaliações.

${ }^{27}$ VELOSO, Mônica P. A Ordem, uma revista de doutrina política e cultura católica. In: Revista de Ciência Política. Rio de Janeiro, 21(3), jul./set. 1978, p. 158.

${ }^{28}$ É o caso de ISAIA, Artur César. Catolicismo e autoritarismo no Rio Grande do Sul. Porto Alegre: Edipucrs, 1998 e SERPA, Élio C. Igreja e poder em Santa Catarina. Florianópolis: Editora da UFSC, 1997.

${ }^{29}$ De acordo com BEOZZO, José Oscar. A Igreja entre a Revolução de 1930, o Estado Novo e a redemocratização. In FAUSTO, Boris. História Geral da Civilização Brasileira. Rio de Janeiro: Bertrand Brasil, 1995, Tomo 3, vol. 4.

${ }^{30}$ Sobre os Círculos, ver BARRETO, Álvaro. Uma avaliação da produção historiográfica sobre os Círculos Operários. In Anos 90, Porto Alegre, nº 7, julho de 1997, pp. 127 a 147; e do mesmo autor Propostas e contradições dos Círculos Operários. Pelotas: Editora da UFPel, 1995.

${ }^{31}$ PIERUCCI, Antônio Flávio de; SOUZA, Beatriz M. de; CAMARGO, Cândido P. de. Igreja Católica: 1945-1970. In FAUSTO, Boris (org.). História Geral da Civilização Brasileira. São Paulo: Difel, 1986, vol. 11, p. 384.

${ }^{32}$ Informações e análises sobre as ações católicas entre os trabalhadores rurais, nas quais estava presente o intuito de combater o comunismo podem ser vistas em: RODEGHERO, Carla Simone. Campo X Cidade: o discurso católico frente à modernização da agricultura no Rio Grande do Sul. In Anos 90, Porto Alegre, jul. 1997, n 7, pp. 148 a 170 e em BRUNEAU, Thomas. Catolicismo brasileiro em época de transição. Petrópolis: Vozes, 1979, pp. 163 a 178.

${ }^{33}$ De acordo com BEOZZO, José Oscar. Op. cit. e ISAIA, Artur César. Op. cit.

${ }^{34}$ Conforme se vê no capítulo 6 de minha tese: Viva o comunismo X Viva Cristo Rei: O México e a Espanha na memória de membros do clero rio-grandense.

${ }^{35}$ A história do pe. Pró é contada em: SANTA CRUZ, Afonso de. Despistou mil secretas. Porto Alegre: Casa Editora da Pia Sociedade Filhas de Maria, 1961.

${ }^{36}$ PIO XI. Divini Redemptoris. São Paulo: Edições Paulinas, 1965, p. 16.

${ }^{37}$ Ver especialmente BRUNEAU, Thomas. Op. cit.

${ }^{38}$ FILENE, Peter. “Cold War Culture” Doesn't Say It All. In: KUZNICK, Peter J. e GILBERT, James (Eds.). Op. cit.

${ }^{39}$ KOVEL, Joel. Op. cit., p. 248.

Artigo recebido em 02/2002. Aprovado em 08/2002. 